Volume 9

Issue 2 Time, Movement, and Space: Genocide

Studies and Indigenous Peoples

Article 13

$10-2015$

\title{
Book Review: Native America and the Question of Genocide
}

Amy Fagin

Beyond Genocide

Follow this and additional works at: https://digitalcommons.usf.edu/gsp

\section{Recommended Citation}

Fagin, Amy (2015) "Book Review: Native America and the Question of Genocide," Genocide Studies and Prevention: An International Journal: Vol. 9: Iss. 2: 125-126.

DOI:

http://dx.doi.org/10.5038/1911-9933.9.2.1278

Available at: https://digitalcommons.usf.edu/gsp/vol9/iss2/13

This Book Review is brought to you for free and open access by the Open Access Journals at Digital Commons @ University of South Florida. It has been accepted for inclusion in Genocide Studies and Prevention: An International Journal by an authorized editor of Digital Commons @ University of South Florida. For more information, please contact digitalcommons@usf.edu. 


\title{
Book Review: Native America and the Question of Genocide
}

\author{
Amy Fagin \\ Beyond Genocide Centre for Prevention
}

Native America and the Question of Genocide

Alex Alvarez

Rowman and Littlefield, 2014.

222 pp. US\$44.00 hbk. US\$43.99 eBook.

Reviewed by Amy Fagin

This review and analysis of the complexities and scale of atrocities perpetrated upon Native America from the $16^{\text {th }}$ through the $20^{\text {th }}$ centuries frames a treatise around the current and debatable question of genocide. In the book's concluding paragraph, it is scholar and historian Paul Bartrop who is given the last word on to the warrant of portraying the accuracy of the complex atrocities perpetrated against the native populations of America. This and future generations are the bearers of this responsibility, and to whom this effort matters most.

The work is organized as a chronological and geographical overture of the Native populations of the Americas extrapolating on the ambiguity that the definition of genocide represents in the context the various crimes associated with mass annihilation: massacres; exterminations; crimes against humanity and genocide as well as war, disease, expropriation and forced assimilation over the past several centuries on said population.

Alvarez's work is a plain-speaking introductory assessment of the perennial debates surrounding the term genocide and its application, legalistically and conceptually, to a selection of relevant Native American experiences during and after colonial invasion and expansion. He weaves together the origins and modern life of Native Americans as they emerge from pre-history to populate the Western Hemisphere and struggle to maintain their threshold from the onslaught of European colonization.

His overture begins with the arrival of the first peoples to the Western Hemisphere from what is believed to be Siberia, some 12,000 to 35,000 years ago; the various tribal groups inhabiting the lands from Beringia to Tierra del Fuego and their first encounters with Norse and Viking voyagers. The chapter shifts abruptly into a survey of the perceptions and mythical ideals of the Noble Savage (20) whereby Alvarez conjectures that this myth contributes in equal measure to the ideologies that ignited conflict and eradication of Native Americans as do negative stereotypes.

Chapter 2 shifts the readers' attention to an introduction of the theoretical principals underlying the term genocide in order to establish and "apply the concept of genocide to the experience of the indigenous peoples of the Americas" (25). The historical formulation of the name; Article II of the United Nations (U.N.) Genocide Convention; and a relevant breakdown of the component parts of the definition are called into play to provide a platform for interpretation and application to the post-contact Native experience. Here Alvarez speculates on the shortcomings and politically designed limitations of the U.N. definition and its pertinence in appraising the history of Native Americans as genocide. How the contested debates around the definition of the term apply to a "potential larger pattern of intentional violence aimed at extermination of the tribes involved" (39) are evaluated in this chapter.

In chapter 3 the interactions between Natives and Europeans are couched in a sociological construct of destructive beliefs condensed into an overview of the role of policies and practices which ideologically fueled the intolerance and violence of the first explorers. The economic underpinnings of European culture and violence are outlined as the thrust of the conflict between Europeans and Natives whereby lust for land, gold and furs of the first traders and settlers described the mentality which led to colonial genocidal processes. Reference to the inherent exterminatory nature of settler colonialism lends currency to the contemporary debates of an overarching social pattern of settler 
colonialism and the inevitability of genocide as a byproduct of this social-phenomena world-wide. Alvarez cautions the reader to understand that "goals and practices often changed and evolved over time as needs and circumstances changed and evolved" and furthermore that individual populations did not uniformly conform to the "destructive beliefs of structural violence" (60).

The onslaught of and vulnerability to disease suffered by Native populations is fleshed out in chapter 4. Its catastrophic impact on the lives of Native populations throughout the hemisphere and centuries is outlined as a major contributor influencing the course of events hedging the victory of colonial-settler conquest. Cases where "disease as a tool of warfare" (85), and consequent genocidal intent, are considered by population and disease type. Alvarez concludes that in understanding genocide and disease there are only isolated cases which link the conceptual framework of "genocide through disease" (87) as a major pattern of intent causing the wholesale destruction of so many Native peoples.

The Sand Creek Massacre of 1864 in Colorado opens the next chapter deliberating the causes and consequences of wars and massacres as theoretical construct of genocide and Native populations of North America. Succinct and carefully composed historical overviews of the Sand Creek Massacre, the Washita River assault, Wounded Knee, the California Gold Rush and the Pequot War are examined within the social and political context of these eras and how each incident or period of history fits the criteria of genocide.

The tragedies of the destroyed and displaced Native populations described in chapter 6, "Exiles in Their Own Land" (119), are woven into a bleak tapestry of the fates of the Navajo and the Cherokee Nations' "horrific tribulations" (129) of forced removals and relocations experienced by some 40 plus tribes in the 19th century. Government policy, military and civilian campaigns of ethnocide are the weft and warp of a textile of tragedy whereby the author aptly conveys the measure of wrenching trauma experienced during this century by its Native populations. The question as to "whether or not these policies constituted genocide...depends on how one uses the term" (140).

In chapter 7 "Education for Assimilation," Alvarez turns chronologically toward the end of the 19th century and into the 20th century with an appraisal of the reservation and boarding school systems established in 1882 with the Carlisle Indian Industrial School. These institutions are taken to task as a gulag (142) system of legally and militarily forced incarcerations facilitating ultimate conquest. The tactics of cultural genocide are clearly laid out in the paradoxical intentions of the dominant culture to forcibly assimilate the remaining Native groups. Alvarez posits an unambiguous argument that cultural genocide would be a prosecutable crime as it pertains to the intended eradication of Native Americans, were it to have been included in the 1948 UN Genocide Convention.

In closing, Alvarez makes a concerted evaluation of the dichotomies inherent in the term genocide as a catchall phrase for its ability / relevance in comprising the lived experiences of the Native populations of the Western Hemisphere. He determines that, ultimately, the intellectual debates surrounding the question of genocide and Native America can only surmise the reality of the people's suffering of this era, but that this effort is summarily relevant to understanding the thresholds of the conceptual terminology of genocide.

This timely volume presents current and relevant theories and their historical underpinnings as a re-construction of Native American history in light of the question of genocide. Alvarez's approach to this treatise is fluid to the point of turbidity however, and the reader must carefully transition, independently, between theoretical and conceptual interpretations and those historical events that serve the theoretical master. The book would be an excellent tool for discussion in a group educational platform. Chapters can be utilized individually, and combined effectively with companion readings to supplement the book's fragmented flow and readability. Combined with relevant readings, a comprehensive analytical understanding to the question of genocide and Native America can be developed with the construct of this discourse. 